\title{
Produksi Gas Hidrogen Berdasarkan Pengaruh Luas Penampang Terhadap Konsentrasi Larutan Elektrolit dan Suplai Arus dengan Metode Elektrolisis
}

\author{
Rahma Eliza $^{* 1}$, Rifat Abdurahman ${ }^{2}$, Agus Manggala ${ }^{3}$, Aisyah Suci Ningsih ${ }^{4}$, Sahrul Effendy A \\ 1,2,3,4,5Program Studi Teknik Energi, Jurusan Teknik Kimia \\ Politeknik Negeri Sriwijaya, Indonesia \\ Email: 1rifatabdurahman942@gmail.com, 2rahma.eliza16@gmail.com
}

\begin{abstract}
Abstrak
Pengembangan energi terbarukan menjadi fokus perhatian saat ini penggunaan sumber energi yang ramah lingkungan dan zero emission dengan pemanfaatan air untuk prosess pembuatan hidrogen melalui proses elektrolisis. Hidrogen adalah gas ringan (lebih ringan dari udara), tidak berwarna dan tidak berbau, jika terbakar tidak menunjukkan adanya nyala dan akan menghasilkan panas yang sangat tinggi, sehingga hidrogen mempunyai potensi yang sangat besar untuk dikembangkan sebagai sumber energi alternatif. Penelitian ini bertujuan untuk menganalisa pengaruh luas penampang dan konsentrasi larutan elektrolit dengan variasi suplai arus listrik terhadap produksi gas hidrogen. Penelitian ini menggunakan metode berupa proses elektrolisis air, larutan elektrolit yang digunakan adalah larutan air garam $(\mathrm{NaCl})$ dengan berlandaskan pada kadar salinitas air laut. Berdasarkan penelitian yang telah dilakukan membuktikan bahwa semakin tinggi konsentrasi larutan elektrolit, semakin besar luas penampang dan semakin tinggi arus yang disuplai maka volume gas yang dihasilkan akan semakin banyak. Hasil yang diperoleh yaitu volume gas $\mathrm{H}_{2}$ tertinggi pada konsentrasi salinitas $35 \mathrm{ppt}$, elektroda ukuran 0,5 in dan kuat arus 35 ampere sebesar 2,118693 liter gas $\mathrm{H}_{2}$ dalam waktu 120 detik. efisiensi tertinggi didapat pada ukuran elektroda 2,0 in ,salinitas 35 ppt dengan kuat arus 15 ampere nilai yang didapat 99,16\% dan daya tertinggi dicapai pada 406 watt pada ukuran elektroda 2,0 in, salinitas 35 ppt pada kuat arus 35 ampere.
\end{abstract}

Kata kunci: Arus listrik, Elektroda, Elektrolisis, Gas hidrogen, Larutan elektrolit.

\section{Hydrogen Gas Production Based on the Effect of Cross-sectional Area on Electrolyte Solution Concentration and Current Supply by Electrolysis Method}

\begin{abstract}
The development of renewable energy is currently the focus of attention on the use of environmentally friendly energy sources and zero emission by utilizing water for the hydrogen production process through the electrolysis process. Hydrogen is a light gas (lighter than air), colorless and odorless, if it burns it does not show a flame and will produce very high heat, so hydrogen has enormous potential to be developed as an alternative energy source. This study aims to analyze the effect of cross-sectional area and concentration of electrolyte solution with variations in the supply of electric current to the production of hydrogen gas. This research uses a method of electrolysis of water, the electrolyte solution used is a salt water solution ( $\mathrm{NaCl}$ ) based on the salinity of seawater. Based on the research that has been done, it is proven that the higher the concentration of the electrolyte solution, the greater the cross-sectional area and the higher the current supplied, the more gas volume will be produced. The result obtained is the highest $\mathrm{H} 2$ gas volume at salinity concentration of $35 \mathrm{ppt}$, electrode size of 0.5 inchi and current strength of 35 ampere of 2.118693 liters of $H 2$ gas in 120 seconds. the highest efficiency is obtained at the electrode size of 2.0 inchi, salinity 35 ppt with a current strength of 15 ampere the value obtained $99.16 \%$ and the highest power achieved at 406 Watts at the electrode size of 2.0 inchi, salinity 35 ppt at the current strength of 35 ampere.
\end{abstract}

Keywords: Electric current, Electrode, Electrolysis, Electrolyte solution, Hydrogen gas.

\section{PENDAHULUAN}

Krisis energi bukan hanya menjadi isu di dunia, tetapi juga menjadi isu di Indonesia. Cadangan minyak dan gas (migas) yang dimiliki Indonesia ternyata takbisa bertahan lama lagi. Pemakaian energi fosil yang terus- 
menerus juga akan menyebabkan pemanasan global akibat sisa pembakarannya yang berupa gas $\mathrm{CO}$ dan $\mathrm{CO} 2$. Maka perlu adanya energi alternatif yang terbarukan (renewable energy) dan ramah lingkungan sebagai sumber energi baru [1].

Saat ini kebutuhan energi di Indonesia sebagian besar masih didominasi oleh penggunaan bahan bakar fosil (batubara, minyak bumi). Ketergantungan terhadap bahan bakar fosil menyebabkan masalah serius seperti menipisnya cadangan minyak bumi, kenaikan harga minyak bumi dan polusi gas akibat pembakaran bahan bakar fosil. Hal ini mendorong para pakar energi untuk mengembangkan energi yang ramah lingkungan salah satunya adalah gas hidrogen.

Hidrogen merupakan bahan bakar yang banyak mendapatkan perhatian untuk dikembangkan, karena merupakan bahan bakar yang ramah lingkungan juga berpotensi menggantikan bahan bakar fosil karena berpotensi menghasilkan zero Emission. Air dapat digunakan sebagai sumber penghasil hidrogen. Mengingat Indonesia dikenal sebagai negara maritim terbesar di dunia, yang 2/3 wilayahnya merupakan wilayah lautan. Dengan demikian, pemanfaatan air merupakan salah satu upaya dalam mengatasi krisis energi di Indonesia [2].

Hidrogen merupakan salah satu upaya dalam mengatasi krisis energi di Indonesia. Gas hidrogen dapat dihasilkan dari proses elektrolisis air menggunakan elekroda logam [3]. Untuk menghasilkan gas hidrogen dengan cara memecah senyawa $\mathrm{H}_{2} \mathrm{O}$ (air) menjadi $\mathrm{HHO}$ (hidrogen hidrogen oksigen) dengan proses elektrolisis dengan bantuan arus listrik searah. Elektrolisis adalah suatu proses untuk memisahkan senyawa kimia menjadi unsurunsurnya atau memproduksi suatu molekul baru dengan memberikan arus listrik. Komponen terpenting dari proses elektrolisis adalah elektroda dan larutan elektrolit [4]. Elektoda yang digunakan pada penelitan ini adalah elektroda berjenis stainless steel type 316L. Wahyono dan Anies [5] dalam penelitiannya menghasilkan gas HHO sebanyak 95,8 $\mathrm{ml}$ dan 82,6 ml. Elektrolit yang digunakan ialah $\mathrm{KOH}$ serta elektroda yang terbuat dari Stainless Steel dengan variasi luas penampang elektroda dengan ukuran $9 \mathrm{~cm}$ x $11 \mathrm{~cm}$ dan $9 \mathrm{~cm}$ x $14 \mathrm{~cm}$.

Produksi gas hidrogen dari larutan elektrolit garam laut yang mengandung $\mathrm{NaCl}$ dapat berlangsung dengan cepat, karena $\mathrm{NaCl}$ sendiri berfungsi sebagai katalis alami. Besar kandungan dari katalis alami atau yang biasa di sebut sebagai salinitas ini berpengaruh terhadap proses elektrolisis. Pada penelitian Yoyon Wahyono dkk [6] dilakukan elektrolisis dengan variasi bahan baku yakni aqua $\mathrm{DM}+\mathrm{NaOH}$, aqua $\mathrm{DM}+\mathrm{NaCl}, \mathrm{Aqua} \mathrm{DM}+\mathrm{NaCl}+$ $\mathrm{NaOH}$ dengan variasi tegangan sebesar $3 \mathrm{~V} ; 6 \mathrm{~V} ; 12 \mathrm{~V}$ pada masing- masing bahan baku. Diperoleh konsentrasi terbaik pada elektrolisis aqua $\mathrm{DM}+\mathrm{NaCl}+\mathrm{NaOH}$ dengan tegangan $12 \mathrm{~V}$ senilai $4500 \mathrm{ppm}$. Gas hidrogen sebagai produk utama dan oksigen yang dihasilkan dari reaksi elektrolisis air membentuk gelembung pada elektroda dan dapat dikumpulkan di suatu penampung. Prinsip ini kemudian dimanfaatkan untuk menghasilkan hidrogen yang dapat digunakan sebagai bahan bakar kendaraan hidrogen [7].

Produksi gas hidrogen dari air laut memang sangat menjanjikan, maka perlu dilakukan pengembangan agar menghasilkan gas hidrogen yang dihasilkan optimal maka perlu dilakukan penelitian lebih lanjut. Tujuan penelitian ini dilakukan untuk menganalisa pengaruh luas penampang dan konsentrasi larutan elektrolit dengan variasi suplai arus listrik terhadap produksi gas hidrogen dengan metode elektrolisis.

\section{METODE PENELITIAN}

Proses elektrolisis dilakukan dengan metode Hydrogen Generator Using Water Electrolysis Process berdasarkan ISO 22734-1:2008 [8] dengan penyesuaian pada desain dan kondisi alat. Adapun proses elektrolisis pada reactor elektrolisis yang digunakan yaitu umpan berupa larutan elektrolit akan dipompakan kedalam elektrolizer dari tangki feed sebanyak 17 liter, kemudian dilakukan proses elektrolisis dengan kuat arus tertentu. Hasil elektolisis yang didapat berupa gas hidrogen dan oksigen yang berada di elektrolizer yang selanjutnya akan ditampung sementara di tangki gas penampung gas $\mathrm{H}_{2}$ dan $\mathrm{O}_{2}$. Selama proses elektrolisis dilakukan pengambilan data selama 2 menit berupa data kondisi operasi berupa tekanan, temperatur dan tegangan, setelah gas hidrogen didapatkan dilakukan perhitungan berdasarkan data yang didapatkan.

\subsection{Waktu dan Tempat}

Proses produksi gas hidrogen ini dilaksanakan di Laboratorium Pilot Plant Jurusan Teknik Kimia Politeknik Negeri Sriwijaya Palembang. Berikut ini uraian waktu dan tempat percobaan:

1. Maintenance dan upgrading Alat Produksi Hidrogen

Waktu : April - Juni 2021

Tempat : Laboratorium Teknik Kimia

Jurusan Teknik Kimia Politeknik Negeri Sriwijaya.

2. Pengujian Alat Produksi Hidrogen 
Waktu : Juli 2021

Tempat : Laboratorium Teknik Kimia

Jurusan Teknik Kimia Politeknik Negeri Sriwijaya.

3. Analisa Hasil percobaan

Waktu : Juli 2021

Tempat : Laboratorium Teknik Kimia

Jurusan Teknik Kimia PoliteknikNegeri Sriwijaya.

\subsection{Alat dan Bahan yang Digunakan}

Alat yang digunakan pada penelitian ini adalah sebagai berikut :

1. Tangki umpan

2. Tabung elektrolizer

3. Tabung gas $\mathrm{H}_{2}$ dan $\mathrm{O}_{2}$

4. Flashback arrestor

5. Control panel

6. Nozzel

7. Pressure gauge

8. Digital temperature detector

Bahan yang digunakan selama penelitian antara lain sebagai berikut :

1. Garam Laut

2. Air Demineralisasi(DM)

3. Listrik PLN

Bahan yang digunakan pada penelitian ini adalah air yang memiliki salinitas 15 ppt, 25 ppt, dan 35 ppt yang diambil dengan sesuai standar pengambilan sampel air laut (SNI 6964.8:2015) [9]. Setelah diketahui salinitas yang menghasilkan gas hidrogen secara optimum dilakukan variasi suplai arus sebesar 15 A, 25 A, dan 35 A lalu untuk ukuran sebesar 0,5 inci, 1 inci, 1,5 inci dan 2 inci. Adapun rancangan alat elektrolisis dapat dilihat pada Gambar 1 .

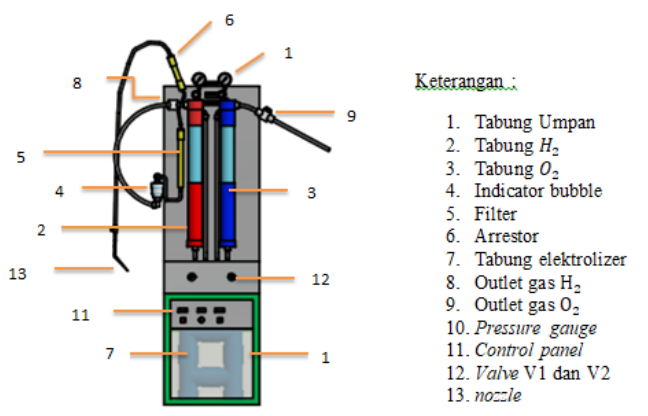

Gambar 1. Rancangan alat produksi hidrogen

\subsection{Persamaan}

Persamaan gas ideal adalah persamaan keadaan suatu gas ideal untuk karakteristik beberapa gas pada kondisi tertentu. Persamaan ini pertama kali dicetuskan oleh Émile Clapeyron tahun 1834 sebagai kombinasi dari Hukum Boyle dan Hukum Charles. Persamaan ini umum dituliskan sebagai

$$
\text { P.V = n.R.T }
$$

dengan $\mathrm{P}$ adalah tekanan mutlak pada gas, $\mathrm{V}$ adalah volume, $\mathrm{n}$ adalah jumlah partikel pada gas (dalam mol), $\mathrm{T}$ adalah temperatur dalam satuan kelvin, dan $\mathrm{R}$ adalah konstanta gas ideal, yaitu 0,08205 L atm mol-1 K-1.Untuk menghitung volume gas yang dihasilkan maka digunakan persamaan gas ideal berikut

$$
\mathrm{V}=\frac{n \cdot R \cdot T}{P}
$$




\section{HASIL DAN PEMBAHASAN}

Pada penelitian produksi hidrogen menggunakan proses elektrolisis larutan elektrolit berupa $\mathrm{DM}+\mathrm{NaCl}$ dilakukan pada tanggal 5 Juli 2021 - 16 Juli 2021 di Laboratorium Teknik Kimia, Politeknik Negeri Sriwijaya. Variabel tetap yang digunakan adalah bahan baku dan jenis elektroda, sedangkan yang mejadi Variabel tidak tetap adalah variasi konenstrasi larutan elektolit, luas penampang elektroda dan kuat arus.

Menurut Mudzakkir [10] semakin besar arus yang digunakan pada proses elektrolisis air maka semakin banyak gas yang dihasilkan. Dari penelitian ini dapat dianalisa bahwa konsentrasi larutan elektrolit, luas penampang dan kuat arus berpengaruh terhadap jumlah gas yang dihasilkan pada proses elektrolisis. Berdasarkan penelitian yang telah dilakukan dan data yang diperoleh, membuktikan bahwa semakin tinggi konsentrasi larutan elektrolit, dan semakin tinggi arus yang disuplai maka volume gas yang dihasilkan akan semakin banyak. Serta semakin besar luas penampang maka proses transfer elektron akan semakin cepat.

Penelitian ini menggunakan Air Demineralisasi(DM) dan Natrium Klorida $(\mathrm{NaCl})$. Dalam pembuatan larutan elektrolit yang menyerupai air laut ini (artificial), $\mathrm{NaCl}$ juga berperan sebagai katalis. Pada air laut alami, garam merupakan katalis alaminya. Katalis adalah suatu zat yag ditambahkan pada reaksi kimia untuk mempercepat reaksi. Pada proses elektrolisis air, katalis dapat digunakan untuk mempercepat reaksi penguraian air menjadi gas $\mathrm{H}_{2}$ dan $\mathrm{O}_{2}$. Maka dari itu, variasi konsentrasi larutan elektrolit dan kuat arus akan menjadi faktor penentu pada proses elektrolisis terhadap jumlah volume gas yang dihasilkan.

Berdasarkan penelitian yang telah dilakukan, diperoleh data volume gas $\mathrm{H}_{2}$ dan $\mathrm{O}_{2}$ hasil proses elektrolisis ditinjau dari konsentrasi larutan elektrolit dan suplai arus listrik. Dari hasil perhitungan, maka jumlah gas $\mathrm{H}_{2}$ dan $\mathrm{O}_{2}$ yang dihasilkan selama dikonversikan ke grafik, dan dapat dilihat pada Gambar berikut.

\subsection{Pengaruh kenaikan konsentrasi larutan elektrolit dan kuat Arus terhadap volume gas $\mathbf{H}_{2}$ yang dihasilkan}

Pada Grafik diatas, terjadi kenaikan volume gas $\mathrm{H}_{2}$ hasil proses elektrolisis yang menggunakan 5 (lima) variasi konsentrasi larutan elektrolit dengan menyesuaikan pada salinitas air laut sesuai dengan bahan baku yang digunakan yaitu air $\mathrm{DM}+\mathrm{NaCl}$ serta 3 (tiga) variasi kuat arus. Volume gas $\mathrm{H}_{2}$ tertinggi diperoleh pada konsentrasi salinitas 35 ppt dan kuat arus 35 ampere sebesar 2,118693 liter gas $\mathrm{H}_{2}$ dalam waktu 120 detik.

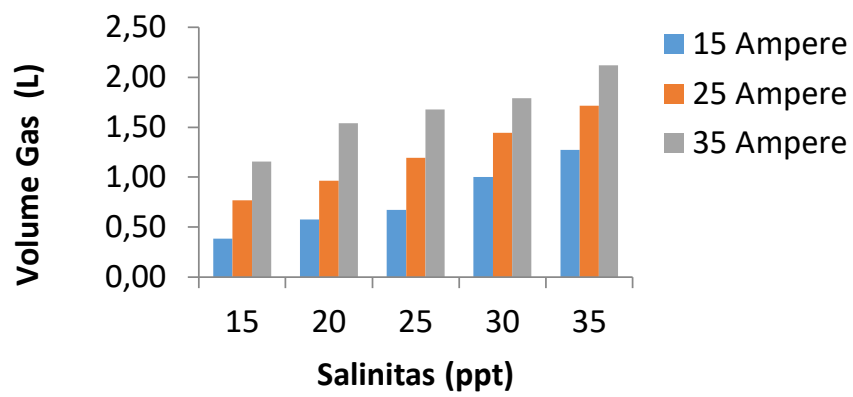

Gambar 2. Grafik Pengaruh Kenaikan Konsentrasi Larutan Elektrolit dan Kuat Arus Terhadap Volume Gas $\mathrm{H} 2$ yang dihasilkan

\subsection{Pengaruh antara luas penampang terhadap volume gas yang dihasilkan}

Untuk Luas penampang elektroda juga sangat berpengaruh pada kecepatan transfer elektron, gambar tersebut. Grafik hubungan antara Luas Penampang dengan volume gas dapat dilihat pada Gambar 2 berikut.

Dari gambar grafik pada 2 gambar menunjukkan bahwa terjadinya transfer elektron pada saat elektrolisis sehingga meningkatnya laju produksi gas hidrogen yang dihasilkan, hal ini ditandai dengan kenaikan arus dari ukuran elektroda yang berbeda. Dari data yang diperoleh hasil pengamatan tidak begitu jauh berbeda setiap ukuran elektroda. Kenaikan volume tertinggi didapatkan pada ukuran elektroda 0,5 didapatkan dengan arus 35A volume gas yang dihasilkan sebesar 0,8960 Liter sedangkan kenaikan volume terendah didapatkan pada ukuran elektroda 2,0 inci pada arus 15 A didapatkan volume gas yang dihasilkan sebesar 0,1915 Liter. Adanya peningkatan arus dan tegangan menyebabkan proses elektrolisis juga berlangsung cepat, karena perpindahan molekul-molekulnya 
juga semakin meningkat, suhu pada proses ini juga mengalami peningkatan disebabkan pergerakan elektron selama proses elektrolis semakin cepat [11].

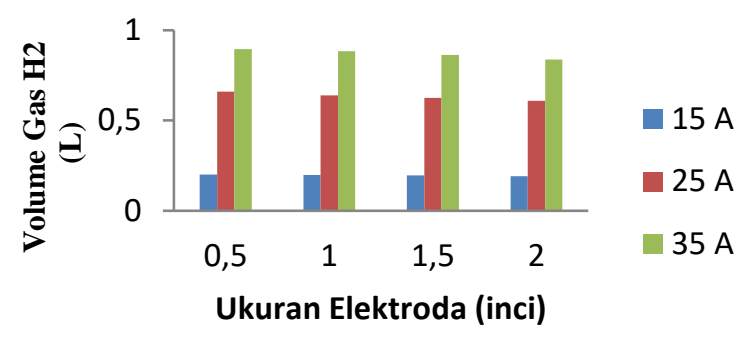

Gambar 3. Grafik Hubungan Antara Luas penampang Dengan Volume Gas Yang Dihasilkan

\section{KESIMPULAN}

Berdasarkan hasil dan pembahasan diatas, maka kesimpulan yang dapat diperoleh adalah sebagai Dari percobaan yang dilakukan dapat ditarik kesimpulan pada penelitian ini yaitu didapatkan volume gas $\mathrm{H}_{2}$ tertinggi pada konsentrasi salinitas 35 ppt dan kuat arus 35 ampere sebesar 2,118693 liter gas $\mathrm{H}_{2}$ dalam waktu 120 detik. Sedangkan pada proses ini volume gas yang dihasilkan tertinggi dengan ukuran elektroda yang berbeda terdapat pada ukuran elektroda dengan diameter 0,5 inci dan tinggi $45 \mathrm{~cm}$ pada arus 35A didapatkan sebesar 0,8960 Liter dengan waktu proses selama 120 detik.

\section{DAFTAR PUSTAKA}

[1] S. Alimah, and E. Dewita, "Pemilihan teknologi produksi hidrogen dengan memanfaatkan energi nuklir," Jurnal Pengembangan Energi Nuklir, vol. 10, no. 2, pp. 123-132, 2008

[2] N. Agustini, "Pengaruh Kosentrasi Larutan NaOH Terhadap Jumlah Hidrogen Yang Dihasilkan Pada Prototype Water Elektrolyzer,” Politeknik Negeri Sriwijaya. Palembang, 2016

[3] Fitriyanti, “Analisis Produktivitas Gas Hidrogen Berdasarkan Arus Dan Tegangan Pada Proses Elektrolisis H2O. Jurusan Fisika, Fakultas Sains Dan Teknologi," Universitas Islam Negeri Alauddin Makassar. Makassar, 2019

[4] S. Marwati, "Pengaruh Agen Pereduksi dalam Proses Elektrodeposisi terhadap Kualitas Deposit Cu dan Ag," Prosiding Seminar Nasional Penelitian, Pendidikan dan Penerapan MIPA, pp. K115-K120, Mei. 18, 2013

[5] Wahyono and Anies, "Pembuatan Alat Produksi Gas Hidrogen Dan Oksigen Tipe Wett Cell Dengan Variasi Luas Penampang," Jurnal Teknik Energi, vol. 12, no. 1, 2016

[6] Y. Wahyono, H. H. Sutanto, and E. Hidayanto, "Produksi gas hydrogen menggunakan metode elektrolisis dari elektrolit air dan air laut dengan penambahan katalis NaOH," Youngster Physics Journal, vol. 6 no. 4, pp. 353-359, 2017

[7] Erlinawati, A. Zikri, and A. Mudzakkir, "Pengaruh Suplai Listrik dan Jumlah Sel Elektroda Terhadap Produksi Gas Hidrohgen dengan Elektrolit Asam Sulfat,” Jurnal Kinetika, vol. 5, no. 1, Palembang, 2014

[8] ISO 22734-1:2008 Hydrogen Generator Using Water Electrolysis Process - Part 1: Industrial and Commercial applications. Diakses pada tanggal 1 September 2020.

[9] SNI 6964.8:2015. Kualitas air laut - Bagian 8 Metode Pengambilan Contoh Air Laut. Diakses pada tanggal 1 September 2020

[10] A. Mudzakkir, "Prototype Hydrogen Fuel Generator (Pengaruh Suplai Arus Listrik dan Jumlah Lempeng Elektroda Terhadap Produksi Gas Hidrogen Dengan Elektrolit Asam Sulfat," Laporan Tugas Akhir. Palembang: Politeknik Negeri Sriwijaya, 2014

[11] Jumiati, J. Sampurno, and I. D. Faryuni, "Pengaruh Konsentrasi Larutan Katalis dan Bentuk Elektroda dalam Proses Elektrolisis untuk Menghasilkan Gas Brown,” Jurnal Positron, vol. 3, no. 1, Pontianak, 2013 